\title{
Measuring flourishing: The impact of operational definitions on the prevalence of high levels of wellbeing
}

\author{
Lucy C. Hone · Aaron Jarden · Grant M. Schofield · Scott Duncan
}

\begin{abstract}
The epidemiology of flourishing is an important research topic prompting international interest in its psychometric assessment. But the need to measure human feelings and functioning at the population level has resulted in the creation of a multitude of different conceptual frameworks of flourishing: a term now commonly used to describe high levels of subjective wellbeing. Not only do different researchers theorise and conceptualise flourishing in different ways, but also the categorical diagnosis of flourishing is dependent upon the various combinations of components, and researcher-determined thresholds, used in each operationalization. The multiplicity of approaches is potentially limiting the usefulness of the resultant epidemiology. This paper comprises two parts: Part 1 identifies four operationalizations of flourishing in the psychology literature and reviews their psychometric properties and utility; Part 2 investigates the impact of operational definition on the prevalence of flourishing using the Sovereign Wellbeing Index survey, a sample of 10,009 adult New Zealanders, and reports substantial variation in prevalence rates according to the four different operationalizations: Huppert and So (24\%), Keyes (39\%), Diener et al. (41\%) and Seligman et al. (47\%). Huppert and So's model was the only one of the four to require endorsement of one particular variable, making it the most stringent criterion for flourishing, while the other three were more flexible in their categorisation. Cross-tabulation analysis indicated strong agreement between our replications of Keyes and Seligman et al.'s models (81\%), and between Diener et al. and Seligman et al.'s models (80\%). Agreement between Seligman, and Huppert and So's, operationalizations was moderate (74\%). Taken together, and in line with recent OECD recommendations, our findings reinforce the need for greater international collaboration and conceptualisation consensus when measuring flourishing. In the absence of any published empirical research investigating perceptions of flourishing among laypersons, a prototype analysis investigating alignment between lay and academic conceptualisations of flourishing is recommended.
\end{abstract}

Keywords: flourishing, conceptualisation, measuring, definition, positive psychology, well-being, wellbeing, epidemiology.

\section{Introduction}

The epidemiology of high levels of wellbeing, referred to here as flourishing, is an important research topic fuelling substantial international interest in its psychometric measurement. Based on the assumption that "well-being would prevail when pathology was absent" (Huppert \& So, 2013, p. 838), epidemiology has traditionally focused on disease. But a growing body of research challenges this assumption, asserting that mental illness and mental health are two separate, albeit related, continua (Keyes, 2002, 2005). Population-based studies investigating the 
prevalence and characteristics of mental health, in addition to mental illness, are therefore vital for providing evidence to support effective population intervention programmes (Lamers, Westerhof, Bohlmeijer, ten Klooster, \& Keyes, 2011). In other words, "as a society, we need to know how people can flourish" (Dunn \& Dougherty, 2008, p. 314). Michaelson and colleagues have identified eight benefits to measuring population wellbeing: to assess change over time; to review and evaluate policy decisions; to enable international comparisons; to assess subgroup differences; to identify future areas of need or opportunity; to evaluate the potential impact of policy proposals; to shape the content and delivery of policy; and to inform targeting of new policies according to population subgroups (Michaelson, Abdallah, Steuer, Thompson, \& Marks, 2009). The growing evidence base of the desirable correlates of high levels of wellbeing (for review see Diener et al., 2010), and the risks to individual and societal-level functioning associated with low levels of wellbeing (Keyes, 2002, 2005, 2010), is convincing policy makers of the importance of complementing objective indicators (e.g. gross domestic product, literacy, and life expectancy) with assessment of subjective wellbeing (Weijers \& Jarden, 2013). As a result, the last decade has seen several countries devise national, or multi-national, surveys designed to empirically measure wellbeing as a multi-dimensional construct. Current national wellbeing surveys come from a variety of sources, both national statistics offices and non-official sources, including for example the European Social Survey (Jowell \& The Central Co-ordinating Team, 2003), the Sovereign Wellbeing Index (Human Potential Centre, 2013), the Australian Unity Wellbeing Index (Cummins, Eckersley, Pallant, van Vugt, \& Misajon, 2003) and Statistics Canada's General Social Survey (Statistics Canada, 2011).

Measures of wellbeing are not only important for governments and decision-makers in organisations, but for the general public too, with polls reflecting a growing appetite among citizens for governments to attend to subjective wellbeing. In one poll, for example, given the choice between pursuing wealth or happiness, $81 \%$ of adults aged 15 and over $(n=1,001)$ believed directing policy towards promoting greater happiness should be the government's primary purpose (Easton, 2006). In another poll, economic measures such as GDP were endorsed as a measure of national wellbeing by just $30 \%$ of respondents $(n=6,870)$, compared to $79 \%$ endorsing 'life satisfaction' as a measure of national wellbeing (ONS UK, 2011). Recently published OECD guidelines on measuring subjective wellbeing have also acknowledged the merit of assessing the views of individuals, providing "an overall picture of well-being that is grounded in people's preferences, rather than in a priori judgements about what should be the most important aspects of well-being" (OECD, 2013, p. 183).

However, for wellbeing outcomes to guide policy in an effective and meaningful way, systematic assessment using reliable, valid, and responsive measurement tools, as well as representative population samples, is required (Diener, Lucas, Schimmack, \& Helliwell, 2009). While substantial progress has been made over the last two decades, with researchers reaching a general consensus that wellbeing is a multi-dimensional construct, and that flourishing refers to high levels of wellbeing (Diener et al., 2010; Fredrickson \& Losada, 2005; Huppert \& So, 2009; Keyes, 2002; Seligman, 2011), the current measurement of wellbeing is haphazard (Diener, 2009; Diener \& Seligman, 2004; Forgeard, Jayawickreme, Kern, \& Seligman, 2011). The presence of multiple measures of flourishing makes it necessary to compare and contrast these models and measures.

This paper has two objectives: Part one reviews the current literature on the most popular psychometric assessments of flourishing, drawing together, for the first time, frequently used conceptualisations and operationalizations. While our review does not claim to be exhaustive, it is, to the best of our knowledge, the first of its kind to summarize the main instruments available 
to measure population flourishing. We begin with a historical review of the psychometric assessments, providing details on each of the researchers' theoretical and conceptual definitions of flourishing, methodologies for categorical diagnosis, and extant evidence of scale reliability and validity. As the theoretical evidence-base for each component indicator of flourishing has been reviewed elsewhere (for example, see Forgeard et al., 2011; Michaelson et al., 2009) this is not the purpose of our investigation; our focus is on comparing the way the components are combined, and categorical definitions of flourishing operationalized, as well as reviewing the research supporting them. Part two investigates the impact of operational definitions on the prevalence of flourishing in New Zealand. Using a large nationally representative sample, and survey data containing sufficient variables, it examines differences and similarities of the prevalence of flourishing as a consequence of conceptualisation and operational definition.

\section{Part One: Literature review}

\subsection{Methods}

Search strategy: Operationalizations of flourishing were identified by several means. Keyword searches in psychological and social science databases were conducted using the following $\mathrm{MeSH}$ terms and text words: "flourish" in combination with "measur" or "assess" or "evaluat" or "scale". The search was restricted to peer-reviewed studies published in the English language. No time criteria were applied. We also checked the references from the studies retrieved.

\subsection{Results}

A total of 71 citations were found and reviewed across the CINAHL (6), MEDLINE (22), Psychology and Behavioral Sciences Collection (5) and PSYCInfo (38) databases. Our search revealed four different conceptualisations and operational definitions of flourishing currently used within the psychological literature: Keyes', Huppert and So's, Diener et al.'s, and Seligman et al.'s.

The first contemporary use of the term flourishing among psychologists to describe high levels of wellbeing was by Corey Keyes. Using a representative sample of adult Americans ( $\mathrm{n}=$ 3,032), Keyes categorised adults free of mental disorder as either flourishing, moderately mentally healthy, or languishing (Keyes, 2002). Following on from Keyes, Huppert and So took advantage of the opportunity afforded by the addition of a new wellbeing module to the 2006/7 European Social Survey (ESS; Jowell \& The Central Co-ordinating Team, 2003) to conduct the first cross-national epidemiological studies of flourishing (Huppert et al., 2009). While Huppert and So's studies cite Keyes' research, they chose not to adopt his operational definition, instead devising, operationalizing and testing their own theoretical and conceptual framework. Next came Diener and colleagues' Flourishing Scale (FS; Diener et al., 2010). The scale was created in acknowledgement that using the Satisfaction with Life Scale (Diener, Emmons, Larsen, \& Griffin, 1985) and an affective measure such as the Positive and Negative Affect Schedule (Watson, Clark, \& Tellegen, 1988) only evaluated emotional wellbeing, and therefore failed to assess areas of positive functioning that evidence indicates to be vital for wellbeing (such as competence, selfacceptance, meaning and relatedness, as well as optimism, giving, and engagement, see Brown, Nesse, Vinokur, \& Smith, 2003; Putnam, 1995; Ryan \& Deci, 2001; Ryff, 1989; Seligman, 2006). Finally, the most recent operationalization of flourishing is the PERMA-Profiler, an acronym representing Seligman's theory that wellbeing requires high levels of positive emotions, engagement, positive relationships, meaning, and accomplishments (PERMA; Seligman, 2011). 
Each of these four different theoretical models, conceptual operationalizations, and the body of science supporting them, is reviewed in greater detail below. They are depicted in Figure 1.

\section{Figure 1. Four different conceptualisations of flourishing}

\begin{tabular}{|c|c|c|c|}
\hline KEYES & HUPPERT \&SO & DIENER et al. & SELIGMAN et al. \\
\hline Positive relationships & Positive relationships & Positive relationships & Positive relationships \\
\hline $\begin{array}{l}\text { Positive affect } \\
\text { (interested) }\end{array}$ & Engagement & Engagement & Engagement \\
\hline Purpose in life & Meaning & Purpose and meaning & Meaning and purpose \\
\hline Self-acceptance & Self-esteem & $\begin{array}{l}\text { Self-acceptance and } \\
\text { Self-esteem }\end{array}$ & - \\
\hline $\begin{array}{l}\text { Positive affect } \\
\text { (happy) }\end{array}$ & Positive emotion & - & Positive emotion \\
\hline- & Competence & Competence & $\begin{array}{l}\text { Accomplishment/ } \\
\text { Competence }\end{array}$ \\
\hline- & Optimism & Optimism & - \\
\hline Social contribution & - & Social contribution & - \\
\hline Social integration & - & - & - \\
\hline Social growth & - & - & - \\
\hline Social acceptance & - & - & - \\
\hline Social coherence & - & - & - \\
\hline Environmental mastery & - & - & - \\
\hline Personal growth & - & - & - \\
\hline Autonomy & - & - & - \\
\hline Life satisfaction & - & - & - \\
\hline- & Emotional stability & - & - \\
\hline- & Vitality & - & - \\
\hline- & Resilience & - & - \\
\hline
\end{tabular}

Note: See Appendix A for SWI indicator items and thresholds selected to replicate each of these conceptualisations for the purposes of part two of this study.

\subsubsection{Keyes' operational definition}

Keyes' polythetic approach, derived by examining the Diagnostic and Statistical Manual's internationally agreed diagnostic criteria and identifying each symptom's opposite (DSM; American Psychiatric Association, 1987), requires the combined presence of high levels of emotional, psychological and social wellbeing symptoms (Keyes, 2002). Hence, in the same way that a diagnosis of depression requires indications of anhedonia and malfunctioning, Keyes requires the presence of hedonic symptoms and positive functioning for a person to be classified as flourishing. His conceptualisation provides self-report assessment of how individuals see themselves functioning personally, as well as evaluating how they see themselves functioning in society. This model of flourishing is underpinned by three theoretical origins: 1) Diener's studies 
on emotional wellbeing (Diener, Suh, Lucas, \& Smith, 1999), 2) Ryff's distinction between hedonic (subjective or emotional) wellbeing and eudaimonic (psychological) wellbeing (Ryff, 1989), and 3) his own studies on social wellbeing (Keyes, 1998).

The 14-item Mental Health Continuum Short Form (MHC-SF; Keyes, 2005) was developed by Keyes in answer to demands for a brief self-rating assessment tool combining all three components of wellbeing. Three items represent emotional wellbeing, six items represent psychological wellbeing, and five items represent social wellbeing. Each item is scored according to respondents' experiences over the last month on a 6-point Likert scale ('never', 'once or twice', 'about once a week', '2 or 3 times a week', 'almost every day', or 'every day') - see Appendix A. This response option was selected to provide a clear standard of mental health assessment and categorisation similar to the DSM methods for assessing Major Depressive Episode. Keyes suggests mental health can be categorised using thresholds for each of the items: participants responding 'almost every day' or 'every day' to one of the three symptoms of emotional wellbeing, and to six of the eleven symptoms of psychological and social wellbeing, are categorised as flourishing. Subscales, dimensions, and indicator items of the MHC-SF are presented in Table 1.

Table 1: Subscales, dimensions, and indicator items on the MHC-SF

\begin{tabular}{ll}
\hline Component of flourishing & $\begin{array}{l}\text { MHC-SF indicator item } \\
\text { During the past month, how often did you feel... }\end{array}$ \\
\hline $\begin{array}{l}\text { Emotional wellbeing } \\
\text { Positive affect } \\
\text { Positive affect }\end{array}$ & $\begin{array}{l}\text { happy } \\
\text { interested in life } \\
\text { Life satisfaction }\end{array}$ \\
$\begin{array}{l}\text { Social wellbeing } \\
\text { Social contribution }\end{array}$ & $\begin{array}{l}\text { that you had something important to contribute to society } \\
\text { that you belonged to a community }\end{array}$ \\
$\begin{array}{l}\text { Social actualisation } \\
\text { Social acceptance }\end{array}$ & $\begin{array}{l}\text { that our society is becoming a better place for people like you } \\
\text { that people are basically good } \\
\text { that the way our society works makes sense to you }\end{array}$ \\
$\begin{array}{l}\text { Psychological wellbeing } \\
\text { Self-acceptance }\end{array}$ & $\begin{array}{l}\text { that you liked most parts of your personality } \\
\text { Pnvironmental mastery }\end{array}$ \\
$\begin{array}{l}\text { Personal growth } \\
\text { good at managing the responsibilities of your daily life } \\
\text { that you had warm and trusting relationships with others } \\
\text { Purpose in life }\end{array}$ & $\begin{array}{l}\text { that you had experiences that challenged you to grow and become } \\
\text { a better person } \\
\text { confident to think or express your own ideas and opinions } \\
\text { that your life has a sense of direction or meaning to it }\end{array}$ \\
\hline
\end{tabular}

Studies using the MHC-SF have reported wide variation in prevalence rates of flourishing from $8 \%$ among South Korean adults (Lim, Ko, Shin, \& Cho, 2013), to 49\% among US college students (Keyes et al., 2012), 20\% flourishing among adult South Africans (Keyes et al., 2008), 23\% flourishing among Egyptian adolescents (Salama-Younes, 2011), and 44\% flourishing among Chinese adults (Yin, He, \& Fu, 2013). Epidemiological studies using the MHC-SF report flourishing is associated with superior physical, psychological, and psychosocial functioning (Keyes, 2005). 
A considerable body of evidence exists to support the reliability, validity, and utility of the MHC. For example, various formats of the MHC have been used to predict the future risk of mental illness among adults (Keyes, Dhingra, \& Simoes, 2010), the risk of all-cause mortality (Keyes \& Simoes, 2012), the risk of suicidality among college students (Keyes et al., 2012), and to predict work-related productivity and health care use (Keyes \& Grzywacz, 2005). It has also been used in behavioural genetics research to examine the heritability of flourishing (Kendler, Myers, Maes, \& Keyes, 2011). The MHC-SF has shown excellent internal consistency and discriminant validity in adolescents and adults across several different countries including the US, the Netherlands, Egypt and South Africa (Keyes, 2006; Keyes \& Grzywacz, 2005; Keyes et al., 2008; Lamers et al., 2011; Salama-Younes, 2011). Lamers and colleagues reported the MHC-SF's testretest reliability at four time points over nine months using item response theory (Lamers et al., 2011). Factor analyses have confirmed the MHC-SF's three-factor structure of emotional, psychological and social wellbeing (Gallagher, Lopez, \& Preacher, 2009; Joshanloo, Wissing, Khumalo, \& Lamers, 2013; Keyes et al., 2008; Lamers et al., 2011; Yin et al., 2013) and metric invariance across cultures (Joshanloo et al., 2013). The MHC-SF has been used in a number of national surveys: the US Panel Study of Income Dynamic's Child Development Supplement (Keyes, 2009); the South Africa Fortology study (Keyes et al., 2008); and the Canadian Community Health Survey (Hubka \& Lakaski, 2013).

\subsubsection{Huppert and So's operational definition}

Huppert and So's theoretical and conceptual definition of flourishing was designed to mirror the internationally agreed upon methodology used in the Diagnostic and Statistical Manual of Mental Disorders (American Psychiatric Association, 2013), as well as the International Classification of Diseases (World Health Organization, 1993), requiring the presence of opposite symptoms to Major Depressive Episode (DSM-IV), Depressive Episode (ICD-10), and Generalised Anxiety Disorder (terminology common to both systems). Identifying the opposite symptoms of these mental illnesses gave Huppert and So a list of ten positive features (competence, emotional stability, engagement, meaning, optimism, positive emotion, positive relationships, resilience, self-esteem, and vitality). They then used ESS data, from a representative sample of 43,000 Europeans, to test their conceptual and operational definition of flourishing, analysing responses from the survey's ten items most closely corresponding to the identified positive features, plus one item assessing life satisfaction (2013). Exploratory factor analysis revealed the presence of three factors, which they referred to as 'positive characteristics' (comprising emotional stability, vitality, optimism, resilience, and self-esteem), 'positive functioning' (comprising engagement, competence, meaning, and positive relationships), and 'positive appraisal' (comprising life satisfaction and positive emotion). Based on factor analysis, inter-item correlations and data distribution, Huppert and So proposed a categorical diagnosis for flourishing that required a strong endorsement of positive emotion, plus a strong endorsement of four out of five 'positive characteristic' features and three out of four 'positive functioning' features (Huppert \& So, 2013). Like Keyes, this method intentionally mirrors the DSM's methodology by not requiring the simultaneous presence of all symptoms, but a specified number. These researchers' conceptualisation also covers both the eudaimonic and hedonic aspects of wellbeing, with the first factor representing hedonia, the second two eudaimonia. Accordingly flourishing "is the combination of feeling good and functioning effectively" (2013, p. 838). Each item is scored according to respondents' experiences using three different Likert scales, with experiences assessed over a range of different time periods, and some items are reverse coded - see Appendix A. Due to the different response scales used in the ESS, Huppert 
and So chose to categorise a feature as present when participants indicated they 'agree' on the seven items using a 5-point scale from 'strongly agree' to 'strongly disagree'. For emotional stability or vitality to be categorised as present, participants were required to respond 'all or almost all of the time' or 'most of the time' on a 4-point scale. However, the data showed such a strong negative skew on the remaining three items that they required 'strongly agree' responses on the two 5-point scales, and 8-10 on the one 0-10 scale. In this sense, Huppert and So's categorisation of flourishing is partly driven by the data's distribution, although they also report that each threshold corresponded to one category above the mean for each item as support for their methodology. Features of flourishing and indicator items from the ESS are presented in Table 2.

Table 2: Features of flourishing and indicator items from the ESS

\begin{tabular}{ll}
\hline Component of flourishing & ESS indicator item \\
\hline Competence & Most days I feel a sense of accomplishment from what I do \\
Emotional stability & (In the past week) I felt calm and peaceful \\
Engagement & I love learning new things \\
Meaning & I generally feel that what I do in my life is valuable and worthwhile \\
Optimism & I am always optimistic about my future \\
Positive emotion & Taking all things together, how happy would you say you are \\
Positive relationships & There are people in my life who really care about me \\
Resilience & When things go wrong in my life it generally takes me a long time to \\
& get back to normal (reverse score) \\
Self-esteem & In general, I feel very positive about myself \\
Vitality & (In the past week) I had a lot of energy \\
\hline
\end{tabular}

Applying their operational definition to the ESS Round 3 (2006/7) dataset Huppert and So reported that $16 \%$ of Europeans were flourishing. National prevalence rates across participating countries showed wide variation from less than $10 \%$ in Slovakia, Russia and Portugal, to $41 \%$ in Denmark (Huppert \& So, 2013). Other than the original study reporting a Spearman correlation between flourishing and life satisfaction of $.34(\mathrm{p}<.01)$, to the best of our knowledge no other studies have assessed the convergence of Huppert and So's model with other wellbeing measures, and the second part of the current study is the first to report prevalence rates of flourishing using their model outside of Europe.

\subsubsection{Diener et al.'s operational definition}

Diener and colleagues created the Flourishing Scale (2010) as a brief summary measure of psychological functioning, designed to complement other measures of subjective wellbeing. The FS was first introduced as the Psychological Flourishing Scale in a 12-item format (Diener \& Biswas-Diener, 2008) but has since been refined to eight items. Based upon earlier humanistic psychology theories, the Flourishing Scale assesses several identified universal human psychological needs, combining these with other theories of wellbeing (Diener et al., 2010). Specifically, the eight-item scale combines dimensions of wellbeing that Ryff (1989), and Ryan and Deci (2001), suggest are important for positive functioning (such as competence, selfacceptance, meaning and relatedness), with optimism, giving, and engagement, which have also been shown to contribute to wellbeing (Brown et al., 2003; Csikszentmihalyi, 1990; Putnam, 1995; Scheier, Carver, \& Bridges, 2001; Seligman, 2006) . 
Each item is phrased in a positive direction using a 7-point Likert scale ranging from 1 (strongly disagree) to 7 (strongly agree). Scores are compiled by adding respondents' scores from each item on the scale together to form one score of psychological wealth (ranging from 8 to 56). While the 12-item version of the FS suggested thresholds categorising participants as flourishing or not flourishing, no such thresholds have been published for the 8-item version. However, a high score on the scale indicates respondents have a positive self-image in important areas of functioning, and many psychological resources and strengths (Diener et al., 2010). Using a representative sample of adult New Zealanders to assess national flourishing, Hone, Jarden and Schofield (2013) report mean FS scores of 43.82 (SD = 8.36).

Several studies have so far confirmed the validity, reliability, and the invariant one-factor structure of the 8-item FS across different populations (Diener et al., 2010; Hone et al., 2013; Khodarahimi, 2013; Silva \& Caetano, 2013). Dogan et al. used the FS in a study examining the relationship between flourishing, self-esteem, emotional self-efficacy and affect balance on happiness (Dogan, Totan, \& Sapmaz, 2013), and the FS was also used alongside other wellbeing measures to test the effectiveness of an on-line occupational health programme in Germany (Feicht et al., 2013). Components of flourishing and indicator items from the Flourishing Scale are presented in Table 3.

Table 3: Components of flourishing and indicator items from the Flourishing Scale

\begin{tabular}{ll}
\hline Component of flourishing & FS indicator item \\
\hline Purpose/meaning & I lead a purposeful and meaningful life \\
Positive relationships & My social relationships are supportive and rewarding \\
Engagement & I am engaged and interested in my daily activities \\
Social contribution & I actively contribute to the happiness and wellbeing of others \\
Competence & I am competent and capable in the activities that are important to me \\
Self-respect & I am a good person and live a good life \\
Optimism & I am optimistic about my future \\
Social relationships & People respect me \\
\hline
\end{tabular}

\subsubsection{Seligman et al.'s operational definition}

Seligman theorises that wellbeing has five components that can be defined and measured as separate, but correlated, constructs (Positive emotions, Engagement, Relationships, Meaning in life, and Accomplishments; PERMA, Seligman, 2011), based on the theoretical grounds that these are what individuals chose freely, "for their own sake" (2011, p.97). The centrality of the theoretical and conceptual role of flourishing to Seligman's interpretation of positive psychology is illustrated in his most recent book, Flourish, in which he writes: "I now think that the topic of positive psychology is well-being, that the gold-standard for measuring well-being is flourishing, and that the goal of positive psychology is to increase flourishing" (Seligman, 2011, p. 13).

The PERMA-Profiler was created in the absence of a brief, validated instrument that specifically measures all five PERMA domains (PERMA-P; Butler \& Kern, in press). Hundreds of theoretically relevant items were compiled to create the measure, tested in a series of studies involving 11,905 participants worldwide, and refined to produce the final measure (for greater detail on the theoretical grounding and methods of testing the PERMA-P see Butler \& Kern, in press). The 16-item PERMA-P has three items representing each of the five PERMA components, and one item representing 'overall wellbeing'. The general wellbeing question serves as a comparison with other population-based surveys. Each item is scored on an 11-point Likert scale, anchored by 0 (never) to 10 (always), or 0 (not at all) to 10 (completely), while experiences are 
assessed via a range of different response scales, for example, 'in general', 'how often', 'to what extent', and 'how much of the time'. Although Seligman lists his criteria for flourishing as being in the upper range of positive emotion, engagement, positive relationships, meaning, and positive accomplishment, Butler and Kern (2013) do not provide thresholds for a categorical diagnosis of flourishing. Instead this research team advocates a 'dashboard' approach to reporting results whereby the three scores of each component are averaged to produce a single component score ranging from 0-10 (higher scores indicate greater wellbeing) and the five component scores are reported as a dashboard of PERMA scores. This, they argue, highlights particular strengths and weaknesses better, whereas a global score lacks the specificity required for targeted intervention and measuring component change over time (in press). As Forgeard et al. mention, "Just as we do not have a single indicator telling us how our car is performing (instead, we have an odometer, a speedometer, a gas gauge, etc.), we suggest that we do not want just one indicator of how well people are doing" (Forgeard et al., 2011, p. 97). As yet, no empirical evidence of dashboard statistics, scale norms, or psychometric properties of the PERMA-P have been published. Butler and Kern suggest their studies demonstrate the scale's acceptable reliability, test-retest stability, and construct validity however, and that factor-analyses confirm the five factor structure (Butler \& Kern, in press). Components of flourishing and indicator items from the PERMA-P are presented in Table 4.

Table 4: Components of flourishing and indicator items from the PERMA-Profiler

\section{Component of flourishing PERMA-P indicator item}

\begin{tabular}{|c|c|}
\hline $\begin{array}{l}\text { Positive } \\
\text { emotion }\end{array}$ & $\begin{array}{l}\text { In general, how often do you feel joyful? } \\
\text { In general, how often do you feel positive? } \\
\text { In general, to what extent do you feel contented? }\end{array}$ \\
\hline Engagement & $\begin{array}{l}\text { How often do you become absorbed in what you are doing? } \\
\text { In general, to what extent do you feel excited and interested in things? } \\
\text { How often do you lose track of time while doing something you enjoy? }\end{array}$ \\
\hline $\begin{array}{l}\text { Positive } \\
\text { relationships }\end{array}$ & $\begin{array}{l}\text { To what extent do you receive help and support from others when you need it? } \\
\text { To what extent have you been feeling loved? } \\
\text { How satisfied are you with your personal relationships? }\end{array}$ \\
\hline Meaning & $\begin{array}{l}\text { In general, to what extent do you lead a purposeful and meaningful life? } \\
\text { In general, to what extent do you feel that what you do in your life is valuable and } \\
\text { worthwhile? } \\
\text { To what extent do you generally feel that you have a sense of direction in your life? }\end{array}$ \\
\hline $\begin{array}{l}\text { Accomplish- } \\
\text { ment }\end{array}$ & $\begin{array}{l}\text { How much of the time do you feel you are making progress towards accomplishing } \\
\text { your goals? } \\
\text { How often do you achieve the important goals you have set for yourself? } \\
\text { How often are you able to handle your responsibilities? }\end{array}$ \\
\hline $\begin{array}{l}\text { General } \\
\text { wellbeing }\end{array}$ & Taking all things together, how happy would you say you are? \\
\hline
\end{tabular}

\subsection{Discussion}

The current review identified four ways different research teams have theorised, conceptualised, and operationalized flourishing, and the published empirical research supporting each model. 
These four research teams (Keyes; Huppert \& So; Diener et al.; and Seligman et al.) have operationalized flourishing differently, but are all in agreement on two matters: one, that flourishing refers to high levels of subjective wellbeing; and two, that wellbeing is a multidimensional construct that cannot be adequately measured using single-item assessment. As our review indicates, not only do they theorise and conceptualise flourishing differently, but also the diagnoses of flourishing are dependent upon the various response scales, combinations of components, and researcher-determined thresholds employed. As we are mindful that different research questions demand different types of psychometric assessment, it is not the aim of our literature review to pigeon-hole these models for specific purposes, but to emphasise their similarities and differences, enabling users to select the appropriate tool for their particular needs. We will turn our attention to these now.

In terms of similarities, all four adopt the theoretical model combining feeling and functioning originally brought together in a conceptual model of flourishing by Keyes (Keyes, 2002). This is important, as studies indicate the usefulness and need of making this distinction for epidemiology (Keyes \& Annas, 2009; Keyes \& Simoes, 2012). As a result, and as depicted in Figure 1, considerable conceptual overlap exists. Engagement appears in all four operationalizations, although in Keyes' model it falls within the emotional wellbeing component as an item assessing 'interest'. All four require endorsement of positive relationships, reflecting the important evidence-based role that relationships have for flourishing. Meaning and purpose also feature in all four operationalizations, although Keyes refers more narrowly to 'purpose in life', Huppert and So to 'meaning', while Diener et al. and Seligman et al. use a broader definition grouping both constructs together. Three require endorsement of positive emotion (Keyes, Huppert and So, and Seligman et al.), and Diener et al.'s Flourishing Scale is often used alongside the Scale of Positive and Negative Affect to achieve simultaneous assessment of emotional wellbeing (for example see Diener et al., 2010; Silva \& Caetano, 2013). Accomplishment appears in the Huppert and So model, Seligman et al.'s definition, and that of Diener et al. (in the form of the 'competence' item); the closest construct in Keyes' version is 'environmental mastery'. The closely associated constructs of self-acceptance and self-esteem feature in three operationalizations (Keyes', Huppert and So's, and Diener et al.'s), but not in the Seligman et al. model. Two key advantages common to all four models are their brevity and clarity: they all assess the multi-dimensional nature of subjective wellbeing in fewer than 20 questions; and none of them require expert delivery. Additionally, all four measures produce data that can be easily interpreted by a wide range of potential end-users working in clinical, policy, and population health promotion contexts. For tools being used in public health these are important considerations; longer surveys may offer greater psychometric rigor, but are not practical.

In terms of differences between the conceptualisations, it is noteworthy that only Keyes includes life satisfaction in his operationalization. While single-item life satisfaction measures, traditionally employed by national statistics offices, have empirically been shown to be inadequate measures of population subjective wellbeing, their complete omission among three of these operationalizations is noteworthy. Given the empirical evidence indicating that life satisfaction and flourishing are separate, but related, constructs (for example see Huppert \& So, 2013), we suggest adding an item assessing life satisfaction alongside Huppert and So, Diener et al. and Seligman et al.'s measures to give a more rounded picture of wellbeing. Other conceptual differences include that optimism features in only two of the four operationalizations (Huppert and So, and Diener et al.), while vitality, and resilience, appear in Huppert and So's definition only. Huppert and So acknowledge that they intentionally omitted constructs that others deem components of optimal functioning, such as autonomy, on the grounds that its opposite does not 
feature in the DSM or ICD diagnostic criteria for depression or anxiety (the basis of their tencomponent conceptualisation). Furthermore, the inclusion of the five social wellbeing items in Keyes' model offers the additional benefit of evaluating individuals' views of their functioning in public life, taking it beyond a measure of purely personal feeling and functioning.

In terms of operationalizational differences, it should be noted that selecting thresholds according to data distribution makes Huppert and So's model the only one in which individual flourishing depends on how well others are doing. The Seligman et al. model is also unique in that it offers brevity while incorporating more than one item per construct as recommended by psychometricians (OECD, 2013).

The most striking difference between the four, however, lies in the imbalance between the substantial body of cross-cultural empirical evidence supporting the psychometric properties and utility of Keyes' model, and the relative paucity of published research behind the three more recently developed models. While psychometric support for, and cross-cultural use of, the Flourishing Scale is growing, Huppert and So's model has not been validated by further studies as far as we know. The second part of the current study is the only example of their model being used to determine national flourishing prevalence outside of Europe. Further testing to determine the PERMA-P's discriminate, predictive, and convergent validity is understood to be forthcoming. Overall, we concur with Butler and Kern that "developing a valid measure of psychological constructs is a long process" (in press, p.18) and more evidence supporting the reliability, validity, and utility of the three newer models is required. In particular, future studies testing the predictive validity of the three newer models alongside Keyes' model would be most helpful for policy makers.

The four conceptual and operational definitions of flourishing reviewed here were devised on a theoretical basis. Our review highlights their commonalities and areas of difference. What it does not tell us, and what we perceive as a gap in the academic literature, is how closely these theoretical conceptualisations of flourishing reflect laypeople's real world understanding of what it is to be flourishing. The failure to agree upon a definition suggests that researchers are unclear what to include and exclude in their definition of flourishing. With four different models to choose from, and three of them so newly devised, we suggest it would be useful and timely to investigate alignment between real world, and academic, understandings of flourishing. The extent to which lay conceptions of flourishing correspond with these models is an empirical question that can and should be answered. For a construct receiving focused academic interest, such as flourishing, it is essential to be confident that what the investigator is measuring corresponds with the concept of flourishing in the mind of participants. We therefore suggest a useful direction for future research would be a prototype analysis (Rosch, 1975) investigating how the layperson perceives the construct of flourishing. Prototype analysis is particularly suited to investigating natural language concepts such as flourishing, which have a "fuzzy collection of features" determining category membership (Lambert, Graham, \& Fincham, 2009, p. 1195), and has been an effective methodology for studies investigating similar constructs such as gratitude (Lambert et al., 2009), forgiveness (Kearns \& Fincham, 2004), and love (Fehr, 1988). The two-step process of prototype analysis, whereby participants are requested in the first stage to freely list all features they associate with flourishing, and subsequently asked to rank them in order of centrality to the construct of flourishing, serves two important purposes. First, the free-response stage will inform researchers of any components of flourishing laypeople consider important that are not captured by the four current versions. Second, ranking each component's centrality enables researchers to establish which of the four models of flourishing reviewed here most closely reflects the lay prototype. A greater understanding of this alignment may facilitate the 
refinement of the construct's measurement, and further inform end-users' decision making when selecting appropriate measurement tools.

\section{Part Two: Investigating the impact of operational definitions on the prevalence of flourishing}

\subsection{Methods}

\subsubsection{Participants}

Participants were obtained from the Sovereign Wellbeing Index Round 1 dataset $(\mathrm{N}=10,009)$, a large, nationally-stratified, representative, random sample of adults over the age of 18 in New Zealand (Jarden et al., 2013). In this study ages ranged from 18 to 111 years, $(\mathrm{M}=44.21, \mathrm{SD}=$ 16.40). Females comprised $53 \%$ of the sample. The majority $(76 \%)$ were European/other, $13 \%$ were Māori/Pacific Islander, and 11\% were Asian. Sixty-one per cent were married or living with a partner, $25 \%$ were single or never married, $11 \%$ were permanently separated or divorced, and $3 \%$ were widowed. Just over a quarter had been educated to the end of secondary school only, $25 \%$ had an apprenticeship, diploma, or trade certificate, and $32 \%$ had gone to university. The majority (59\%) were employed, 34\% were not in the labour force and $7 \%$ were unemployed. The sample aligned with population parameters from the NZ census (Statistics New Zealand, 2006). For more descriptive statistics see the SWI Executive Report (Human Potential Centre, 2013).

\subsubsection{Measures}

Keyes' flourishing: Keyes' MHC-SF was replicated using selected items from the SWI. While the SWI contains 87 items assessing wellbeing, the fit between SWI variables and MHC-SF was not perfect. For the MHC-SF items evaluating 'social contribution' and 'social integration' we were forced to choose the SWI item most closely capturing the original construct. Full details of selected items and thresholds on the survey's various response scales selected to diagnose flourishing are listed in Appendix A. In the absence of any suitable SWI item representing 'social coherence' it had to be excluded from our analysis. The MHC-SF requires individuals to report experiencing at least seven of the 14 symptoms 'everyday' or 'almost everyday', rated on a 6point Likert scale, to be categorised as flourishing. The absence of any questions in the SWI relating to 'social coherence' meant that instead of requiring individuals to endorse one of the three emotional wellbeing items, and six out of 11 symptoms of 'positive functioning' (social wellbeing and psychological wellbeing combined), we required one of three emotional wellbeing items and six out of ten symptoms of 'positive functioning' to be diagnosed as flourishing in the SWI replication of Keyes' model. Additionally, because the SWI used a variety of different response scales (not just the 6-point Likert scale of the MHC-SF), we selected appropriate categorical thresholds replicating the sense of the MHC-SF as best we could, but also basing our decisions on theoretical justification and face validity.

Huppert and So's flourishing: Having modelled the SWI survey on the ESS Round 6 we were able to replicate the questionnaire items in Huppert and So's (2013) operationalization of flourishing. While the SWI used the same questions as the ESS, the response scales were slightly different. While replicating the original authors' methodology of basing thresholds on descriptive statistics would have allowed for accurate international comparison, we chose to determine each item's threshold according to theoretical justification and face validity, as described above. This approach was deemed preferable considering a primary purpose of our study was to compare operational definitions, so adopting a threshold methodology that we could apply uniformly both within each operationalization and across the four 
operationalizations was important. Furthermore, we wanted to avoid making (potentially erroneous) assumptions about the prevalence of flourishing that taking a data-driven approach to defining thresholds involves.

Diener et al.'s Flourishing Scale: The inclusion of the 8-item Flourishing Scale in the SWI enabled exact replication of Diener et al.'s operationalization of flourishing. In its original 12item format, with scores ranging from 12 to 84, Diener and Biswas-Diener (2008) suggested summed scores 60 and above represented flourishing, while summed scores below 60 indicated the absence of flourishing. As the published studies using the 8-item FS only report mean and percentile rank scores, and no cut points or component combinations required for categorical diagnoses (Hone et al., 2013; Silva \& Caetano, 2013), we determined that individuals with total scores of 48 and above be categorised as flourishing (remembering that scores range from 7 to 56 , and the response scale ranged from 1 'strongly disagree' to 7 'strongly agree' on the 8-item FS). While we acknowledge the somewhat arbitrary nature of this threshold for categorisation, we again justify selection on rational and theoretical grounds rather than offering numerical justification: total scores of 48 and above require individuals to 'agree' (6) or 'strongly agree' (7) on average across the scale's eight items. In this sense our approach mirrors Keyes', and Huppert and So's, in not requiring the simultaneous presence of all symptoms.

Seligman et al.'s flourishing: Seligman's PERMA-Profiler was replicated using selected items from the SWI. Given the scale's authors have not devised a categorical diagnosis of flourishing using the PERMA-P, and have not identified thresholds at this time (personal communication, 22 November, 2013) we devised our own categorical diagnosis mirroring Keyes', and Huppert and So's, empirically supported schema. Again, the variety of response scales used in the SWI forced us to select thresholds for each component, and as above, these were selected on theoretical grounds and face validity rather than being data-driven. To be categorised as flourishing therefore required individuals to endorse four out of five components of PERMA, where endorsement meant scoring above our identified threshold on two of any three items belonging to each component. Like Keyes, and Huppert and So's, conceptualisations, this method mirrors the DSM's methodology of requiring the simultaneous presence of a majority, but not all, of the symptoms.

\subsubsection{Statistical analysis}

Calculating the prevalence of flourishing: Categorical diagnoses of flourishing according to our interpretation of the four different operational definitions were applied to the SWI data to estimate prevalence of flourishing among New Zealand adults. This was achieved by following several steps. First, we created new dichotomous variables distinguishing between those participants endorsing each individual component of flourishing and those not, by determining appropriate response thresholds. Our methodology and rationale for establishing thresholds is detailed in the measures section above (also see Appendix A). We then replicated each of the four different operational definitions' combinations of components to distinguish between flourishers and non-flourishers.

Investigating the relationship between different operationalizations of flourishing: First we conducted cross tabulation analysis to investigate percentage agreement and Spearman's correlation between each of the four flourishing measures. Next we used pairwise McNemar tests for related samples to determine if the differences between pairs of measures were significant, and Cochrane's $Q$ test to determine significance between all four measures. Finally, Cronbach's alpha was calculated to analyse internal consistency between measures. 


\subsection{Results}

\subsubsection{Calculating the prevalence of flourishing}

In this study, $39 \%$ of adults met the criteria for flourishing according to our replication of Keyes' model, $24 \%$ met the criteria for flourishing according to our replication of Huppert and So's model, $41 \%$ met the criteria for flourishing according to our replication of Diener et al.'s model, and $47 \%$ met the criteria for flourishing according to our replication of Seligman's model.

\subsubsection{Investigating the relationship between different operationalizations}

Cross tabulation analysis revealed that the SWI replications of Keyes' and Seligman et al.'s operationalizations of flourishing were the most closely related $(81 \%$ agreement, $r=.62)$, followed by the SWI replications of Diener et al. and Seligman et al.'s operationalizations (80\% agreement, $\mathrm{r}=.59)$, Keyes' and Huppert and So's operationalizations (78\% agreement, $\mathrm{r}=.54)$, Diener et al. and Keyes' operationalizations (77\% agreement, $r=.52)$, Diener et al. and Huppert and So's operationalizations (75\% agreement, $\mathrm{r}=.48)$, and Seligman et al. and Huppert and So's operationalizations (74\% agreement, $\mathrm{r}=.53)$. See Table 5 for percentage of agreement and Spearman's correlations between each of the four operationalizations.

Table 5: Percentage of agreement and Spearman's correlations for different operationalizations of flourishing

\begin{tabular}{|c|c|c|c|c|c|c|c|c|}
\hline & \multicolumn{2}{|c|}{ Keyes } & \multicolumn{2}{|c|}{ Huppert \& So } & \multicolumn{2}{|c|}{ Diener et al. } & \multicolumn{2}{|c|}{ Seligman et al } \\
\hline & 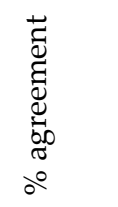 & $\begin{array}{l}\stackrel{0}{0} \\
\frac{\pi}{0} \\
\stackrel{0}{0} \\
0 \\
0\end{array}$ & 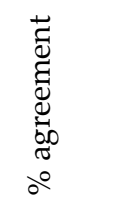 & $\begin{array}{l}\stackrel{0}{0} \\
\frac{\pi}{0} \\
\stackrel{0}{0} \\
0 \\
0\end{array}$ & 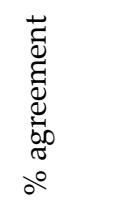 & $\begin{array}{l}\tilde{D} \\
\frac{0}{\pi} \\
\stackrel{0}{0} \\
0\end{array}$ & 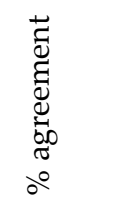 & 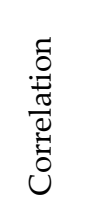 \\
\hline Keyes & $100 \%$ & 1 & & & & & & \\
\hline Huppert and So & $78 \%$ & $.54^{*}$ & $100 \%$ & 1 & & & & \\
\hline Diener et al. & $77 \%$ & $.52^{*}$ & $75 \%$ & $.48^{*}$ & $100 \%$ & 1 & & \\
\hline Seligman et al. & $81 \%$ & $.62^{*}$ & $74 \%$ & $.53^{*}$ & $80 \%$ & $.59^{*}$ & $100 \%$ & 1 \\
\hline
\end{tabular}

* Significance level is .05

\subsubsection{Reliability analysis}

Reliability analysis indicated that internal consistency between the four SWI replications of different categorical diagnoses of flourishing was relatively good, with a Cronbach alpha coefficient of .83. A two-way random effects model, where both people effects and measures effects are random, indicated that the average intraclass correlation between any two measures was .53, CI $[.49, .56]$. The average intraclass correlation across all four measures was .82, CI [.79, $.84]$.

\subsection{Discussion}

Part two of this paper estimated flourishing prevalence rates among 10,009 adult New Zealanders, according to replications of each of the four frequently used operationalizations of flourishing identified in part one, using the SWI variables and dataset. Results indicated there 
was a substantial difference in prevalence rates of flourishing depending upon the operationalization employed, from 24\% (Huppert \& So), to 39\% (Keyes), 41\% (Diener et al.), and $47 \%$ (Seligman et al.). The low prevalence rate of flourishing from the SWI replication of Huppert and So's conceptualisation (24\%) most likely reflects their more stringent theoretical and conceptual criteria for flourishing: to be categorised as flourishing participants are required to endorse the one item representing positive emotion (which only $41 \%$ of the sample did), plus three out of four components of 'positive functioning', and four out of five components of 'positive characteristics'; thereby allowing participants to score below the thresholds on only two out of ten items. In contrast, participants could score below the thresholds on six out of 13 components in the SWI replication of Keyes' operationalization, or seven out 15 items in the SWI replication of Seligman et al.'s operationalization, and still be categorised as flourishing. In only requiring an average score of 48 and above, our interpretation of Diener et al.'s operationalization also allowed greater flexibility across components than our interpretation of Huppert and So's operationalization. (This is the most striking difference between these four operationalizations, and the cause of the variation in prevalence rates.) It is important to note that the use of different response formats in the SWI survey meant that some of the variation in prevalence rates between our study and previous studies might be due to the use of different thresholds, making for potentially inaccurate international comparisons. For example, New Zealand's $24 \%$ flourishing according to our replication of Huppert and So's model may not be directly comparable to the Danes' $41 \%$ flourishing or Portugal's $10 \%$ flourishing diagnosed using the same model (Huppert \& So, 2013). However, by applying consistent methodology for selecting thresholds across all four models in our study, we are confident that the flourishing prevalence rates according to the four different models are comparable with each other in our study.

While related samples Cochrane's $Q$ tests indicated all four operationalizations were significantly different to one another, cross tabulation analysis revealed a strong agreement between our replications of Keyes' and Seligman et al.'s operationalizations (81\%) and Diener et al. and Seligman et al.'s (80\%). Even the least comparable operationalizations (Huppert and So and Seligman et al.) indicated moderate agreement $(74 \%)$. In the absence of an established empirical benchmark stating what degree of agreement is meaningful, or indeed any criterion for interpreting what these levels of agreement mean, it is hard to draw any concrete conclusions from these findings.

The strengths and unique contributions of this study include the application of the four operational definitions to a very large, nationally representative, sample of adults, which allows our results to be compared to other population samples; the prospective nature of the SWI, with two more longitudinal rounds scheduled over the next four years, allowing us to monitor the prevalence of flourishing among New Zealand adults over time using all four operationalizations; and the use of cross-tabulation and pairwise Cochrane's $Q$ tests allowing us to calculate, for the first time, the degree of agreement between the SWI replications of the different measures commonly employed to assess flourishing.

In terms of limitations, we experienced challenges in accurately replicating three of the four operationalizations of flourishing using the available dataset (the FS was replicated exactly). While the SWI's large number of wellbeing variables $(n=87)$ presented us with a compelling opportunity to compare these operationalizations, we acknowledge that the fit was not perfect. Differences in questionnaire items and response formats required us to make subjective decisions regarding the best way to replicate the original models. The challenge was to stay true to the theory and conceptualisation of the original models, while also remaining consistent in our 
methodology across models. We offer the following four examples of the types of challenges we faced, and our methods for overcoming them.

Firstly, the absence of any categorical diagnosis of flourishing for the Flourishing Scale or PERMA-P required us to devise our own methods. We were guided by Keyes, and Huppert and So, in our methodology. This meant selecting a threshold for flourishing on the FS that allowed endorsement of most, but not necessarily all, of the scale's eight components (scores $\geqslant 48$, range 7-56, meaning respondents had to score an average of six on the 7-point Likert scale). To be categorised as flourishing in the SWI replication of the PERMA-P required participants to score above a threshold on two of three items of each component, and four out of the five components overall. While we acknowledge the limitations in our approach, and acknowledge the PERMA$P$ research team's preference for dashboard reporting, categorical diagnoses of flourishing provide vital information for decision makers.

Secondly, the various items selected and response formats used in the SWI frequently differed from those in the original scales. For instance, while the response option for the MHCSF measured the frequency with which respondents experienced each component over the past month, several items in the SWI asked respondents "how much of the time during the past week" or "how much of the time would you generally say...". Where possible we used the same items as the original scale, but some could not be matched to an SWI variable (such as 'social coherence'), which meant this component had to be excluded from our analysis. Others were matched, but not perfectly so, leaving us having to choose the item which came closest to representing the original construct. Some of these were far from ideal. For instance, the MHC-SF item for 'social growth' ("during the past month, how often did you feel our society is a good place, or is becoming a better place for all people?") was operationalized using the reverse-scored SWI item "For most people in New Zealand life is getting worse rather than better". Similarly, Keyes' 'social contribution' item assesses respondents' contribution at a societal level, while the SWI item has a greater focus on the individual. The MHC-SF's 'social integration' item concerning belonging to a community could be interpreted to refer to any type of group or community, in contrast to the SWI item we were forced to use, which reflects respondents' perceptions of people in their local area. In this sense we cannot claim to have replicated Keyes' validated scale completely. The SWI items selected to match the PERMA-P were also not a perfect replication, but we were at least able to include three different items for each PERMA construct, allowing us to represent the original scale well in this regard. Despite these obvious limitations, we maintain that having such a large number of wellbeing variables in the SWI, a large representative sample, and the FS and ESS models represented in their entirety, made comparison of the four models a worthwhile exercise.

Thirdly, the greatest single challenge involved the decision making around the selection of thresholds differentiating between participants endorsing a component of flourishing and those not endorsing a component. Recently published OECD guidelines on measuring wellbeing suggest the use of thresholds as "one way to manage a large number of scale responses" (OECD, 2013, p. 187). Thresholds provide a useful way of conveying aspects of the data's distribution with a single figure, and are compatible with the SWI's ordinal data. However, the OECD guidelines also caution that great care must be taken when selecting thresholds: "there is considerable risk that a threshold positioned in the wrong part of the scale could mask important changes in the distribution of the data" (2013, p. 188). The OECD recommends examining data distribution (particularly watching for the tendency for strong negative skew common to subjective wellbeing responses), using median and mean statistics to help identify tipping points, and selecting scale values above which empirical evidence suggests positive outcomes are 
associated. The OECD also acknowledges that a key challenge lies in combining a data-driven approach with the identification of thresholds that are meaningful and have real-world utility. With this in mind, and considering the purpose of this study was to examine measurement equivalence across four different operationalizations, we needed to find a methodology we could apply consistently both within each definition, and across all four different operationalizations. Concerned that Huppert and So's approach of selecting thresholds based upon the distribution of data made (potentially erroneous) assumptions about the prevalence of flourishing, and influenced the reported prevalence rates substantially, we instead selected thresholds above which empirical evidence suggests positive outcomes are associated. These were based on face validity, and our theoretical knowledge of flourishing and subjective wellbeing. Essentially, we asked, 'What is the lowest score with which a participant could respond to this question and still be deemed to be flourishing?' For example, on the SWI question "Please indicate how much of the time during the past week you felt calm and peaceful", we deemed a score of two or above to be characteristic of flourishing, so that participants responded that they felt calm and peaceful at least 'some of the time'. One of the key outcomes to come from conducting this review and analysis is the way it highlighted the critical role that decisions regarding the location of thresholds play in determining prevalence rates of population flourishing, and the challenges involved in using a categorical approach to defining and measuring flourishing. But taking a categorical approach is important: it is the appropriate method for calculating prevalence, and mean scores give no indication of the number of people experiencing high wellbeing (Huppert \& So, 2013). Our methodology and rationale for establishing thresholds is detailed in the measures section above (also see Appendix A).

Fourthly, a further limitation is that most components of flourishing were represented by a single item in the SWI. While it would have been better to have more than one item representing each symptom of wellbeing, reducing the size of error, population studies such as the SWI are designed with considerations of participant overload and time burden in mind. Similarly, the lack of objective measures represents a further limitation. As researchers we appreciate the value of employing subjective and objective measures simultaneously, given the ability of each to provide important insights for policy makers. After all, we want citizens to have "both decent objective standards of living and feel subjectively satisfied with their lives" (Forgeard et al., 2011, p. 99). However, the requirements of balancing questionnaire breadth and depth prevented the inclusion of any data beyond self-report, and also precluded the measurement of other potentially associated variables such as personality traits.

\section{Summary}

This paper reviewed the state of research on the psychometric measurement of flourishing, a term used by psychologists and social scientists to describe high levels of wellbeing. Measuring human flourishing is important. Objective measures of progress are informative, but provide only limited insight into prosperity at the population level. A considerable body of empirical evidence now indicates that flourishing is a desirable condition that any community, organisation, or government would benefit from protecting and promoting among its citizens. Measures of flourishing tend to be more stable over time than does affect, and international research has indicated significantly better individual and public health outcomes associated with flourishing (Howell, 2009; Huppert, 2004, 2009; Keyes, 2002, 2005, 2010; Keyes \& Haidt, 2003). As a result, demand is growing for the collection and publication of measures of subjective wellbeing and epidemiological work on flourishing. A literature search identified four different theoretical, conceptual, and operational definitions of flourishing currently being used by 
psychological researchers and statisticians. Following Corey Keyes' (2002) model, three more models have recently been devised and conceptualised (Diener et al., 2010; Huppert et al., 2009; Seligman, 2011). Substantially more published research currently supports Keyes' model than the other three. Despite sharing theoretical and conceptual similarities, the four models produce substantially different prevalence rates when replicated using SWI variables and data, therefore limiting the usefulness of the resultant epidemiology. While we recognise that the psychometrics of flourishing is in its infancy, and that substantial empirical progress has been made in this endeavour, for psychometric measures to be useful they must be collated in a consistent manner, which requires a consensus around theoretical, conceptual and operational definitions. Until an identical measurement approach is adopted across countries, we cannot rule out the possibility that observed national differences reflect methodological differences. OECD guidelines on measuring wellbeing emphasise that comparability is of the highest priority: "Whether comparisons are to be made over time or between groups of respondents, the guidelines argue in favour of adopting a consistent measurement approach across all survey instruments, study waves and countries wherever possible, to limit the additional variance potentially introduced by differing methodologies" (OECD, 2013, p. 14). We agree. But, we also understand that this consensus takes time and further research. In light of this, and the lack of published empirical research exploring lay perceptions of flourishing, we recommend a prototype analysis be conducted to examine alignment between lay and academic conceptions, and investigation of which of the four models reviewed here fits with lay opinion most closely. Our study suggests that clinicians, policy makers and citizens stand to benefit significantly from standardisation of measurement tools.

\section{Acknowledgements}

The authors would like to acknowledge Sovereign as the funder of this research.

\section{Authors}

Lucy C. Hone

Auckland University of Technology

lucy.hone@aut.ac.nz

Aaron Jarden

Auckland University of Technology

Grant M. Schofield

Auckland University of Technology

Scott Duncan

Auckland University of Technology

Publishing Timeline

Received 18 December 2013

Accepted 29 April 2014

Published 5 June 2014

\section{References}

American Psychiatric Association. (1987). Diagnostic and statistical manual of mental disorders (3rd ed.). Washington, DC: American Psychiatric Association. 
American Psychiatric Association. (2013). Diagnostic and statistical manual of mental disorders. Arlington, VA.

Brown, S. L., Nesse, R. M., Vinokur, A. D., \& Smith, D. M. (2003). Providing social support may be more beneficial than receiving it: results from a prospective study of mortality. Psychological Science 14(4), 320-327. http://dx.doi.org/10.1111/1467-9280.14461

Butler, J., \& Kern, M. L. (2013). The PERMA-Profiler: A brief multidimensional measure of flourishing International Positive Psychology Association. Los Angeles.

Butler, J., \& Kern, M. L. (in press). The PERMA-Profiler: A brief measure of flourishing. Philadelphia, PA.

Csikszentmihalyi, M. (1990). Flow: The psychology of optimal experience. New York: Harper Collins.

Cummins, R. A., Eckersley, R., Pallant, J., van Vugt, J., \& Misajon, R. (2003). Developing a national index of subjective wellbeing: The Australian Unity Wellbeing Index. Social Indicators Research, 64 (2), 159190. http://dx.doi.org/10.1023/A:1024704320683

Diener, E. (2009). Assessing well-being: The collected works of Ed Diener (Vol. 3). Oxford, UK: Springer. http://dx.doi.org/10.1007/978-90-481-2354-4

Diener, E., \& Biswas-Diener, R. (2008). Happiness: Unlocking the mysteries of psychological wealth. Malden, MA: Blackwell Publishing. http://dx.doi.org/10.1002/9781444305159

Diener, E., Emmons, R. A., Larsen, R. J., \& Griffin, S. (1985). The Satisfaction With Life Scale. Journal of Personality Assessment, 49(1), 71-75. http://dx.doi.org/10.1207/s15327752jpa4901_13

Diener, E., Lucas, R., Schimmack, U., \& Helliwell, J. (2009). Well-being for public policy. New York: Oxford University Press. http://dx.doi.org/10.1093/acprof:oso/9780195334074.001.0001

Diener, E., \& Seligman, M. E. (2004). Beyond money: Toward an economy of well-being. Psychological Science in the Public Interest, 5, 1-31. http://dx.doi.org/10.1111/j.0963-7214.2004.00501001.x

Diener, E., Suh, E. M., Lucas, R. E., \& Smith, H. L. (1999). Subjective well-being: Three decades of progress. Psychological Bulletin, 125(2), 276-302. http://dx.doi.org/10.1037/0033-2909.125.2.276

Diener, E., Wirtz, D., Tov, W., Kim-Prieto, C., Choi, D. W., Oishi, S., \& Biswas-Diener, R. (2010). New well-being measures: short scales to assess flourishing and positive and negative feelings. Social Indicators Research, 97(2), 143-156. http://dx.doi.org/10.1007/s11205-009-9493-y

Dogan, T., Totan, T., \& Sapmaz, F. (2013). The role of self-esteem, psychological well-being, emotional self-efficacy, and affect balance on happiness: a path model. European Scientific Journal, 9(20), 31-42.

Dunn, D. S., \& Dougherty, S. B. (2008). Flourishing: Mental health as living life well. Journal of Social and Clinical Psychology, 27(3), 314-316. http://dx.doi.org/10.1521/jscp.2008.27.3.314

Easton, M. (2006). Britain's happiness in decline. http://news.bbc.co.uk/1/hi/programmes/happiness_formula/4771908.stm

Fehr, R. (1988). Prototype analysis of the concepts of love and commitment. Journal of Personality and Social Psychology, 55(4), 557-579. http://dx.doi.org/10.1037/0022-3514.55.4.557

Feicht, T., Wittmann, M., Jose, G., Mock, A., von Hirschhausen, E., \& Esch, T. (2013). Evaluation of a seven-week web-based happiness training to improve psychological well-being, reduce stress, and enhance mindfulness and flourishing: A randomized controlled occupational health study. EvidenceBased Complementary and Alternative Medicine, 2013,1-14. http://dx.doi.org/10.1155/2013/676953

Forgeard, M. J. C., Jayawickreme, E., Kern, M. L., \& Seligman, M. E. (2011). Doing the right thing: Measuring wellbeing for public policy. International Journal of Wellbeing, 1(1), 79-106. http://dx.doi.org/10.5502/ijw.v1i1.15

Fredrickson, B. L., \& Losada, M. F. (2005). Positive affect and the complex dynamics of human flourishing. American Psychologist, 60(7), 678-686. http://dx.doi.org/10.1037/0003-066X.60.7.678

Gallagher, M. W., Lopez, S. J., \& Preacher, K. J. (2009). The hierarchical structure of well-being. Journal of Personality, 77(4), 1025-1050. http://dx.doi.org/10.1111/j.1467-6494.2009.00573.x

Hone, L. C., Jarden, A., \& Schofield, G. (2013). Psychometric properties of the Flourishing Scale in a New Zealand sample. Social Indicators Research, 1-15. http://dx.doi.org/10.1007/s11205-013-0501-x

Howell, A. J. (2009). Flourishing: Achievement-related correlates of students' well-being. The Journal of Positive Psychology, 4(1), 1-13. http://dx.doi.org/10.1080/17439760802043459 
Hubka, D., \& Lakaski, C. (2013). Developing research and surveillance for positive mental health: A Canadian process for conceptualization and measurement. International Journal of Mental Health and Addiction, 11(6), 658-671. http://dx.doi.org/10.1007/s11469-013-9443-4

Human Potential Centre. (2013). Sovereign Wellbeing Index: New Zealand's first measure of wellbeing. Auckland, NZ: Auckland University of Technology.

Huppert, F. A. (2004). A population approach to positive psychology: The potential for population interventions to promote well-being and prevent disorder. In A. Linley \& S. Joseph (Eds.), Positive psychology in practice. Hoboken, NJ: John Wiley \& Sons.

Huppert, F. A. (2009). Psychological well-being: Evidence regarding its causes and consequences. Applied Psychology: Health and Well-Being, 1(2), 137-164. http://dx.doi.org/10.1111/j.1758-0854.2009.01008.x

Huppert, F. A., Marks, N., Clark, A., Siegrist, J., Stutzer, A., Vitters, J., \& Wahrendorf, M. (2009). Measuring well-being across Europe: Description of the ESS Well-being Module and preliminary findings. Social Indicators Research, 91, 301-315. http://dx.doi.org/10.1007/s11205-008-9346-0

Huppert, F. A., \& So, T. C. (2009). What percentage of people in Europe are flourishing and what characterises them? presented at the meeting of the OECD/ISQOLS meeting, July 23/24 2009, Florence.

Huppert, F. A., \& So, T. C. (2013). Flourishing across Europe: Application of a new conceptual framework for defining well-being. Social Indicators Research, 110(3), 837-861. http://dx.doi.org/10.1007/s11205-011-9966-7

Jarden, A., MacKay, L., White, K., Schofield, G., Duncan, S., Williden, M., ... McPhee, J. (2013). The Sovereign New Zealand Wellbeing Index. Psychology Aotearoa, 5(1), 22-27.

Joshanloo, M., Wissing, M. P., Khumalo, I. P., \& Lamers, S. M. A. (2013). Measurement invariance of the Mental Health Continuum-Short Form (MHC-SF) across three cultural groups. Personality and Individual Differences, 55(7), 755-759. http://dx.doi.org/10.1016/j.paid.2013.06.002

Jowell, R., \& The Central Co-ordinating Team. (2003). European Social Survey 2002/3: Technical report. London: Centre for Comparative Social Surveys, City University.

Kearns, J. N., \& Fincham, F. D. (2004). A prototype analysis of forgiveness. Personality and Social Psychology Bulletin, 30(7), 838-855. http://dx.doi.org/10.1177/0146167204264237

Kendler, K. S., Myers, J. M., Maes, H. H., \& Keyes, C. L. M. (2011). The relationship between the genetic and environmental influences on common internalizing psychiatric disorders and mental well-being. Behavior Genetics, 41(5), 641-650. http://dx.doi.org/10.1007/s10519-011-9466-1

Keyes, C. L. M. (1998). Social well-being. Social Psychology Quarterly, 61(2), 121-140. http://dx.doi.org/10.2307/2787065

Keyes, C. L. M. (2002). The Mental Health Continuum: From languishing to flourishing in life. Journal of Health and Social Behavior, 43(2), 207-222. http://dx.doi.org/10.2307/3090197

Keyes, C. L. M. (2005). Mental illness and/or mental health? Investigating axioms of the complete state model of health [Research Support, Non-U.S. Gov't]. Journal of Consulting and Clinical Psychology, 73(3), 539-548. http://dx.doi.org/10.1037/0022-006X.73.3.539

Keyes, C. L. M. (2006). Mental health in adolescence: is America's youth flourishing? American Journal of Orthopsychiatry, 76(3), 395-402. http://dx.doi.org/10.1037/0002-9432.76.3.395

Keyes, C. L. M. (2009). The nature and importance of positive mental health in America's adolescents. . In R. Gilman, E. S. Huebner, \& M. J. Furlong (Eds.), Handbook of positive psychology in schools. (pp. 9-23). New York: Routledge.

Keyes, C. L. M. (2010). The next steps in the promotion and protection of positive mental health. CJNR (Canadian Journal of Nursing Research), 42(3), 17-28.

Keyes, C. L. M., \& Annas, J. (2009). Feeling good and functioning well: distinctive concepts in ancient philosophy and contemporary science. Journal of Positive Psychology, 4(3), 197-201 http://dx.doi.org/10.1080/17439760902844228

Keyes, C. L. M., Dhingra, S. S., \& Simoes, E. J. (2010). Change in level of positive mental health as a predictor of future risk of mental illness. American Journal of Public Health, 100(12), 2366. http://dx.doi.org/10.2105/AJPH.2010.192245

Keyes, C. L. M., Eisenberg, D., Perry, G. S., Dube, S. R., Kroenke, K., \& Dhingra, S. S. (2012). The relationship of level of positive mental health with current mental disorders in predicting suicidal 
behavior and academic impairment in college students. Journal of American College Health, 60(2), 126133. http://dx.doi.org/10.1080/07448481.2011.608393

Keyes, C. L. M., \& Grzywacz, J. G. (2005). Health as a complete state: the added value in work performance and healthcare costs [Research Support, Non-U.S. Gov't]. Journal of Occupational and Environmental Medicine / American College of Occupational and Environmental Medicine, 47(5), 523-532. http://dx.doi.org/10.1097/01.jom.0000161737.21198.3a

Keyes, C. L. M., \& Haidt, J. (2003). Flourishing : positive psychology and the life well-lived (1st ed.). Washington, DC: American Psychological Association. http://dx.doi.org/10.1037/10594-000

Keyes, C. L. M., \& Simoes, E. J. (2012). To flourish or not: Positive mental health and all-cause mortality. American Journal of Public Health, 102(11), 2164-2172. http://dx.doi.org/10.2105/AJPH.2012.300918

Keyes, C. L. M., Wissing, M., Potgieter, J. P., Temane, M., Kruger, A., \& van Rooy, S. (2008). Evaluation of the Mental Health Continuum -Short Form (MHC-SF) in Setswana-speaking South Africans. Clinical Psychology \& Psychotherapy, 15(3), 181-192. http://dx.doi.org/10.1002/cpp.572

Khodarahimi, S. (2013). Hope and flourishing in an Iranian adults sample: Their contributions to the positive and negative emotions. Applied Research in Quality of Life, 8(3), 361-372. http://dx.doi.org/10.1007/s11482-012-9192-8

Lambert, N. M., Graham, S. M., \& Fincham, F. D. (2009). A prototype analysis of gratitude: Varieties of gratitude experiences. Personality and Social Psychology Bulletin, 35(9), 1193-1207. http://dx.doi.org/10.1177/0146167209338071

Lamers, S. M. A., Westerhof, G. J., Bohlmeijer, E. T., ten Klooster, P. M., \& Keyes, C. L. M. (2011). Evaluating the psychometric properties of the Mental Health Continuum-Short Form (MHC-SF). Journal of Clinical Psychology, 67(1), 99-110. http://dx.doi.org/10.1002/jclp.20741

Lim, Y.-J., Ko, Y.-G., Shin, H.-C., \& Cho, Y. (2013). Prevalence and correlates of complete mental health in the South Korean adult population. In C. L. M. Keyes (Ed.), Mental well-being: International contributions to the study of positive mental health (pp. 91-109): Springer. http://dx.doi.org/10.1007/97894-007-5195-8_5

Michaelson, J., Abdallah, S., Steuer, N., Thompson, S., \& Marks, N. (2009). National Accounts of Wellbeing: bringing real wealth onto the balance sheet. London: New Economics Foundation. http://www.nationalaccountsofwellbeing.org/learn/download-report.html

OECD. (2013). OECD Guidelines on Measuring Subjective Well-being: OECD Publishing. http://dx.doi.org/10.1787/9789264191655-en

ONS UK. (2011). Initial investigation into Subjective Well-being from the Opinions Survey. Newport: ONS. http://www.ons.gov.uk/ons/rel/wellbeing/measuring-subjective-wellbeing-in-the-uk/investigationof-subjective-well-being-data-from-the-ons-opinions-survey/initial-investigation-into-subjectivewell-being-from-the-opinions-survey.html

Putnam, R. D. (1995). Bowling alone: America's declining social capital. Journal of Democracy, 6(1), 65-78. http://dx.doi.org/10.1353/jod.1995.0002

Rosch, E. (1975). Cognitive representations of semantic categories. Journal of Experimental Psychology: General, 104(3), 192-233. http://dx.doi.org/10.1037/0096-3445.104.3.192

Ryan, R. M., \& Deci, E. L. (2001). On happiness and human potentials: A review of research on hedonic and eudaimonic well-being. Annual Review of Psychology, 52(1), 141-166. http://dx.doi.org/10.1146/annurev.psych.52.1.141

Ryff, C. D. (1989). Happiness is everything, or is it? Explorations on the meaning of psychological wellbeing. Journal of Personality \& Social Psychology, 57(6), 1069-1081. http://dx.doi.org/10.1037/00223514.57.6.1069

Salama-Younes, M. (2011). Validation of the Mental Health Continuum Short Form and Subjective Vitality Scale with Egyptian adolescent athletes. In I. Brdar (Ed.), The human pursuit of well-being (pp. 221-234): Springer Netherlands. http://dx.doi.org/10.1007/978-94-007-1375-8_19

Scheier, M. F., Carver, C. S., \& Bridges, M. W. (2001). Optimism, pessimism, and psychological wellbeing. In E. C. Chang (Ed.), Optimism \& pessimism: Implications for theory, research, and practice (pp. 189-216). Washington, DC: American Psychological Association. http://dx.doi.org/10.1037/10385-009 
Seligman, M. E. (2006). Learned optimism: How to change your mind and your life (1st Vintage Books ed.). New York: Vintage Books.

Seligman, M. E. (2011). Flourish: A visionary new understanding of happiness and well-being (1st Free Press hardcover ed.). New York, NY: Free Press.

Silva, A. J., \& Caetano, A. (2013). Validation of the flourishing scale and scale of positive and negative experience in Portugal. Social Indicators Research 110(2), 469-478. http://dx.doi.org/10.1007/s11205-0119938-y

Statistics Canada. (2011). General Social Survey - 2010. Ottawa.

Statistics New Zealand. (2006). 2006 New Zealand Census data. http://www.stats.govt.nz/Census/about2006-census/2006-census-reports.aspx

Watson, D., Clark, I. A., \& Tellegen, A. (1988). Development and validation of brief measures of positive and negative affect: The PANAS scales. Journal of Personality and Social Psychology, 54(6), 1063-1070. http://dx.doi.org/10.1037/0022-3514.54.6.1063

Weijers, D., \& Jarden, A. (2013). The science of happiness for policymakers: An overview. Journal of Social Research \& Policy, 4(2) 21-40.

World Health Organization. (1993). ICD-10 Classification of mental and behavioural disorders: Diagnostic criteria for research. Geneva, Switzerland: World Health Organisation.

Yin, K. L., He, J. M., \& Fu, Y. F. (2013). Positive mental health: Measurement, prevalence, and correlates in a Chinese cultural context. In C. L. M. Keyes (Ed.), Mental well-being: International contributions to the study of positive mental health. Dordrecht: Springer. http://dx.doi.org/10.1007/978-94-007-5195-8 
Appendix A. Features of flourishing, original indicator items according to each operationalization, selected SWI indicator items, thresholds and threshold frequencies

\begin{tabular}{|c|c|c|c|c|}
\hline $\begin{array}{c}\text { Operation- } \\
\text { alization \& } \\
\text { Construct }\end{array}$ & Original Indicator Item & $\begin{array}{l}\text { Selected SWI Indicator } \\
\text { Item }\end{array}$ & $\begin{array}{c}\text { Thresholds: } \\
\text { Participant categor- } \\
\text { ised as endorsing } \\
\text { this feature if SWI } \\
\text { score = }\end{array}$ & $\begin{array}{l}\% \text { of SWl } \\
\text { sample } \\
\text { above thi } \\
\text { threshold }\end{array}$ \\
\hline \multicolumn{5}{|l|}{ Keyes } \\
\hline Positive affect & $\begin{array}{l}\text { During the past month, } \\
\text { how often did you feel } \\
\text { happy? (1-6; never to } \\
\text { every day) }\end{array}$ & $\begin{array}{l}\text { Please indicate, how } \\
\text { much of the time during } \\
\text { the past week you were } \\
\text { happy? (1-4; } \\
\text { none/almost none of the } \\
\text { time-all/almost all) }\end{array}$ & $\geq 2$ & $68 \%$ \\
\hline Positive affect & $\begin{array}{l}\text { During the past month, } \\
\text { how often did you feel } \\
\text { interested in life? (1-6; } \\
\text { never to every day) }\end{array}$ & $\begin{array}{l}\text { How much of the time } \\
\text { would you generally say } \\
\text { you are interested in } \\
\text { what you are doing? (0- } \\
\text { 10; none of the time-all } \\
\text { of the time) }\end{array}$ & $\geq 8$ & $40 \%$ \\
\hline $\begin{array}{c}\text { Life } \\
\text { satisfaction }\end{array}$ & $\begin{array}{l}\text { During the past month, } \\
\text { how often did you feel } \\
\text { satisfied with life? (1-6; } \\
\text { never to every day) }\end{array}$ & $\begin{array}{l}\text { All things considered, } \\
\text { how satisfied are you } \\
\text { with your life as a whole } \\
\text { nowadays ( } 0-10 \text {; } \\
\text { extremely dissatisfied- } \\
\text { extremely satisfied) }\end{array}$ & $\geq 8$ & $39 \%$ \\
\hline $\begin{array}{c}\text { Social } \\
\text { contribution }\end{array}$ & $\begin{array}{l}\text { During the past month, } \\
\text { how often did you feel } \\
\text { you had something } \\
\text { important to contribute } \\
\text { to society? (1-6; never to } \\
\text { every day) }\end{array}$ & $\begin{array}{l}\text { I generally feel that what } \\
\text { I do in my life is } \\
\text { valuable and } \\
\text { worthwhile (1-5; } \\
\text { strongly disagree- } \\
\text { strongly agree) }\end{array}$ & $\geq 4$ & $71 \%$ \\
\hline $\begin{array}{c}\text { Social } \\
\text { integration }\end{array}$ & $\begin{array}{l}\text { During the past month, } \\
\text { how often did you feel } \\
\text { you belonged to a } \\
\text { community? (1-6; never } \\
\text { to every day) }\end{array}$ & $\begin{array}{l}\text { I feel close to the people } \\
\text { in my local area (1-5; } \\
\text { strongly disagree- } \\
\text { strongly agree) }\end{array}$ & $\geq 4$ & $25 \%$ \\
\hline Social growth & $\begin{array}{l}\text { During the past month, } \\
\text { how often did you feel } \\
\text { our society is a good } \\
\text { place, or is becoming a } \\
\text { better place for all } \\
\text { people? (1-6; never to } \\
\text { every day) }\end{array}$ & $\begin{array}{l}\text { For most people in NZ } \\
\text { life is getting worse } \\
\text { rather than better REV } \\
\text { (1-5; strongly disagree- } \\
\text { strongly agree) }\end{array}$ & $\geq 3$ & $51 \%$ \\
\hline
\end{tabular}




\section{Operation- alization \& Construct}

Original Indicator Item

Selected SWI Indicator Item

\section{Thresholds: \\ Participant categor- \\ ised as endorsing \\ this feature if SWI \\ score $=$ \\ $\%$ of SWI \\ sample \\ above this \\ threshold}

Keyes

\begin{tabular}{|c|c|c|c|c|}
\hline $\begin{array}{c}\text { Social } \\
\text { acceptance }\end{array}$ & $\begin{array}{l}\text { During the past month, } \\
\text { how often did you feel } \\
\text { that people are basically } \\
\text { good? (1-6; never to } \\
\text { every day) }\end{array}$ & $\begin{array}{l}\text { Generally speaking, } \\
\text { most people can be } \\
\text { trusted, or you can't be } \\
\text { too careful ( } 0-10 \text {; can't be } \\
\text { too careful/most people } \\
\text { can be trusted) }\end{array}$ & $\geq 8$ & $14 \%$ \\
\hline $\begin{array}{c}\text { Social } \\
\text { coherence }\end{array}$ & $\begin{array}{l}\text { During the past month, } \\
\text { how often did you feel } \\
\text { the way our society } \\
\text { works makes sense to } \\
\text { you? (1-6; never to every } \\
\text { day) }\end{array}$ & $\mathrm{n} / \mathrm{a}$ & $\mathrm{n} / \mathrm{a}$ & $\mathrm{n} / \mathrm{a}$ \\
\hline Self-acceptance & $\begin{array}{l}\text { During the past month, } \\
\text { how often did you feel } \\
\text { that you liked most } \\
\text { parts of your } \\
\text { personality? (1-6; never } \\
\text { to every day) }\end{array}$ & $\begin{array}{l}\text { In general, I feel very } \\
\text { positive about myself (1- } \\
5 ; \text { strongly disagree- } \\
\text { strongly agree) }\end{array}$ & $\geq 4$ & $67 \%$ \\
\hline $\begin{array}{c}\text { Environmental } \\
\text { mastery }\end{array}$ & $\begin{array}{l}\text { During the past month, } \\
\text { how often did you feel } \\
\text { good at managing the } \\
\text { responsibilities of your } \\
\text { daily life? (1-6; never to } \\
\text { every day) }\end{array}$ & $\begin{array}{l}\text { How difficult or easy do } \\
\text { you find it to deal with } \\
\text { important problems that } \\
\text { come up in your life? ( } 0 \text { - } \\
\text { 10; extremely difficult- } \\
\text { extremely easy) }\end{array}$ & $\geq 6$ & $62 \%$ \\
\hline $\begin{array}{c}\text { Positive } \\
\text { relationships }\end{array}$ & $\begin{array}{l}\text { During the past month, } \\
\text { how often did you feel } \\
\text { you had warm and } \\
\text { trusting relationships } \\
\text { with others? (1-6; never } \\
\text { to every day) }\end{array}$ & $\begin{array}{l}\text { How often do you meet } \\
\text { socially with friends, } \\
\text { relatives (1-7; never- } \\
\text { every day) }\end{array}$ & $\geq 6$ & $30 \%$ \\
\hline $\begin{array}{l}\text { Personal } \\
\text { growth }\end{array}$ & $\begin{array}{l}\text { During the past month, } \\
\text { how often did you feel } \\
\text { you had experiences that } \\
\text { challenged you to grow } \\
\text { and become a better } \\
\text { person? (1-6; never to } \\
\text { every day) }\end{array}$ & $\begin{array}{l}\text { To what extent do you } \\
\text { learn new things in your } \\
\text { life? (0-6; not at all-a } \\
\text { great deal) }\end{array}$ & $\geq 5$ & $44 \%$ \\
\hline
\end{tabular}




\section{Operation- alization \& Construct \\ Keyes \\ During the past month, how often did you feel \\ Autonomy confident to think/ \\ Purpose in life express your own ideas and opinions? (1-6; never to every day) \\ During the past month, how often did you feel your life has a sense of direction? (1-6; never to every day)}

$\begin{array}{ll}\text { Original Indicator Item } & \begin{array}{l}\text { Selected SWI Indicator } \\ \text { Item }\end{array}\end{array}$

$\begin{array}{cc}\begin{array}{c}\text { Thresholds: } \\ \text { Participant categor- } \\ \text { ised as endorsing }\end{array} & \begin{array}{c}\text { sample } \\ \text { sabove this }\end{array} \\ \text { this feature if SWI } & \begin{array}{c}\text { above } \\ \text { threshold }\end{array} \\ \text { score }= & \end{array}$

I am free to decide for myself how to live my life (1-5; strongly $\geq 4$ $70 \%$ disagree-strongly agree)

To what extent do you feel you have a sense of direction (0-10; not at $\geq 8$ $35 \%$ all-completely)

\begin{tabular}{|c|c|c|c|c|}
\hline $\begin{array}{l}\text { Huppert \& } \\
\text { So }\end{array}$ & & & & \\
\hline Competence & $\begin{array}{l}\text { Most days I feel a sense } \\
\text { of accomplishment from } \\
\text { what I do (1-5; strongly } \\
\text { agree-strongly disagree) }\end{array}$ & $\begin{array}{l}\text { Most days I feel a sense } \\
\text { of accomplishment from } \\
\text { what I do (1-5; strongly } \\
\text { agree-strongly disagree) }\end{array}$ & $\geq 4$ & $58 \%$ \\
\hline $\begin{array}{l}\text { Emotional } \\
\text { stability }\end{array}$ & $\begin{array}{l}\text { In the past week, I felt } \\
\text { calm and peaceful (1-4; } \\
\text { none or almost none of } \\
\text { the time-all or almost all } \\
\text { of the time) }\end{array}$ & $\begin{array}{l}\text { Please indicate, how } \\
\text { much of the time during } \\
\text { the past week you felt } \\
\text { calm and peaceful? (1-4; } \\
\text { none/almost none of the } \\
\text { time-all/almost all) }\end{array}$ & $\geq 2$ & $88 \%$ \\
\hline Engagement & $\begin{array}{l}\text { I love learning new } \\
\text { things (1-5; strongly } \\
\text { agree-strongly disagree) }\end{array}$ & $\begin{array}{l}\text { To what extent do you } \\
\text { learn new things in your } \\
\text { life? (0-6; not at all-a } \\
\text { great deal) }\end{array}$ & $\geq 5$ & $44 \%$ \\
\hline Meaning & $\begin{array}{l}\text { I generally feel that what } \\
\text { I do in my life is } \\
\text { valuable and } \\
\text { worthwhile (1-5; } \\
\text { strongly agree-strongly } \\
\text { disagree) }\end{array}$ & $\begin{array}{l}\text { I generally feel that what } \\
\text { I do in my life is } \\
\text { valuable and } \\
\text { worthwhile (1-5; } \\
\text { strongly agree-strongly } \\
\text { disagree) }\end{array}$ & $\geq 4$ & $71 \%$ \\
\hline Optimism & $\begin{array}{l}\text { I am always optimistic } \\
\text { about my future (1-5; } \\
\text { strongly agree-strongly } \\
\text { disagree) }\end{array}$ & $\begin{array}{l}\text { I am always optimistic } \\
\text { about my future (1-5; } \\
\text { strongly agree-strongly } \\
\text { disagree) }\end{array}$ & $\geq 4$ & $62 \%$ \\
\hline
\end{tabular}


Operationalization \& Construct
Original Indicator Item

Selected SWI Indicator Item

\begin{tabular}{|c|c|}
\hline $\begin{array}{l}\text { Thresholds: } \\
\text { Participant categor- } \\
\text { ised as endorsing } \\
\text { this feature if SWI }\end{array}$ & $\begin{array}{l}\% \text { of SWI } \\
\text { sample } \\
\text { above this } \\
\text { threshold }\end{array}$ \\
\hline
\end{tabular}

\begin{tabular}{|c|c|c|c|c|}
\hline $\begin{array}{l}\text { Huppert \& } \\
\text { So }\end{array}$ & & & & \\
\hline $\begin{array}{l}\text { Positive } \\
\text { emotion }\end{array}$ & $\begin{array}{l}\text { Taking all things } \\
\text { together, how happy } \\
\text { would you say you are? } \\
\text { (0-10; extremely } \\
\text { unhappy-extremely } \\
\text { happy) }\end{array}$ & $\begin{array}{l}\text { Taking all things } \\
\text { together, how happy } \\
\text { would you say you are? } \\
\text { (0-10; extremely } \\
\text { unhappy-extremely } \\
\text { happy) }\end{array}$ & $\geq 8$ & $41 \%$ \\
\hline $\begin{array}{l}\text { Positive } \\
\text { relationships }\end{array}$ & $\begin{array}{l}\text { There are people in my } \\
\text { life who really care } \\
\text { about me (1-5; strongly } \\
\text { agree-strongly disagree) }\end{array}$ & $\begin{array}{l}\text { To what extent do you } \\
\text { receive help and support } \\
\text { from people you are } \\
\text { close to when you need } \\
\text { it? (0-6; not at all- } \\
\text { completely) }\end{array}$ & $\geq 4$ & $68 \%$ \\
\hline Resilience & $\begin{array}{l}\text { When things go wrong } \\
\text { in my life it generally } \\
\text { takes me a long time to } \\
\text { get back to normal (1-5; } \\
\text { strongly agree-strongly } \\
\text { disagree) }\end{array}$ & $\begin{array}{l}\text { When things go wrong } \\
\text { in my life it generally } \\
\text { takes me a long time to } \\
\text { get back to normal (1-5; } \\
\text { strongly disagree- } \\
\text { strongly agree) REV }\end{array}$ & $\geq 4$ & $45 \%$ \\
\hline Self-esteem & $\begin{array}{l}\text { In general, I feel very } \\
\text { positive about myself (1- } \\
\text { 5; strongly agree to } \\
\text { strongly disagree) REV }\end{array}$ & $\begin{array}{l}\text { In general, I feel very } \\
\text { positive about myself (1- } \\
5 \text {; strongly disagree- } \\
\text { strongly agree) }\end{array}$ & $\geq 4$ & $67 \%$ \\
\hline Vitality & $\begin{array}{l}\text { In the past week, I had a } \\
\text { lot of energy (1-4;none } \\
\text { or almost none of the } \\
\text { time-all or almost all of } \\
\text { the time) }\end{array}$ & $\begin{array}{l}\text { During the past week, } \\
\text { how much of the time } \\
\text { did you have a lot of } \\
\text { energy? (1-4; none or } \\
\text { almost none of the time- } \\
\text { all or almost all) }\end{array}$ & $\geq 3$ & $39 \%$ \\
\hline
\end{tabular}

\section{Diener et al.}

I lead a purposeful and

Purposel meaningful life (1-7;

Meaning strongly disagreestrongly agree)

My social relationships

Positive relationships are supportive and rewarding (1-7; strongly disagree-strongly agree)
I lead a purposeful and meaningful life (1-7; strongly disagreestrongly agree

My social relationships are supportive and rewarding (1-7; strongly disagree-strongly agree) 
Operationalization \& Construct
Original Indicator Item

Selected SWI Indicator Item

$\begin{array}{cc}\begin{array}{c}\text { Thresholds: } \\ \text { Participant categor- } \\ \text { ised as endorsing }\end{array} & \begin{array}{c}\text { sample } \\ \text { sabove this }\end{array} \\ \text { this feature if SWI } & \begin{array}{c}\text { above } \\ \text { threshold }\end{array} \\ \text { score }= & \end{array}$

\section{Diener et al.}

\begin{tabular}{|c|c|c|}
\hline Engagement & $\begin{array}{l}\text { I am engaged and } \\
\text { interested in my daily } \\
\text { activities (1-7; strongly } \\
\text { disagree-strongly agree) }\end{array}$ & $\begin{array}{l}\text { I am engaged and } \\
\text { interested in my daily } \\
\text { activities (1-7; strongly } \\
\text { disagree-strongly agree) }\end{array}$ \\
\hline $\begin{array}{c}\text { Social } \\
\text { contribution }\end{array}$ & $\begin{array}{l}\text { I actively contribute to } \\
\text { the happiness and } \\
\text { wellbeing of others }\end{array}$ & $\begin{array}{l}\text { I actively contribute to } \\
\text { the happiness and } \\
\text { wellbeing of others }\end{array}$ \\
\hline Competence & $\begin{array}{l}\text { I am competent and } \\
\text { capable in the activities } \\
\text { that are important to me } \\
\text { (1-7; strongly disagree- } \\
\text { strongly agree) }\end{array}$ & $\begin{array}{l}\text { I am competent and } \\
\text { capable in the activities } \\
\text { that are important to me } \\
\text { (1-7; strongly disagree- } \\
\text { strongly agree) }\end{array}$ \\
\hline Self-respect & $\begin{array}{l}\text { I am a good person and } \\
\text { live a good life (1-7; } \\
\text { strongly disagree- } \\
\text { strongly agree) }\end{array}$ & $\begin{array}{l}\text { I am a good person and } \\
\text { live a good life (1-7; } \\
\text { strongly disagree- } \\
\text { strongly agree) }\end{array}$ \\
\hline Optimism & $\begin{array}{l}\text { I am optimistic about } \\
\text { my future(1-7; strongly } \\
\text { disagree-strongly agree) }\end{array}$ & $\begin{array}{l}\text { I am optimistic about } \\
\text { my future(1-7; strongly } \\
\text { disagree-strongly agree) }\end{array}$ \\
\hline $\begin{array}{c}\text { Social } \\
\text { relationships }\end{array}$ & $\begin{array}{l}\text { People respect me (1-7; } \\
\text { strongly disagree- } \\
\text { strongly agree) }\end{array}$ & $\begin{array}{l}\text { People respect me (1-7; } \\
\text { strongly disagree- } \\
\text { strongly agree) }\end{array}$ \\
\hline
\end{tabular}

\section{Seligman et al.}

$\begin{array}{ll}\begin{array}{l}\text { Positive } \\ \text { emotion }\end{array} & \begin{array}{l}\text { In general, how often do } \\ \text { never-always) }\end{array}\end{array}$

Positive emotion
In general, how often do you feel positive? (0-10; never-always)
Please indicate, how much of the time during the past week you enjoyed life? (1-4; $\geq 2$ $67 \%$ none/almost none of the time-all/almost all)

Please indicate, how much of the time during the past week you were happy? (1-4; $\geq 2 \quad 68 \%$ none/almost none of the time-all/almost all) 
Operationalization \&

Construct
Original Indicator Item
Selected SWI Indicator Item

$\begin{array}{cc}\text { Thresholds: } & \text { \% of SWI } \\ \text { Participant categor- } & \text { sample } \\ \text { ised as endorsing } & \text { above this } \\ \text { this feature if SWI } & \text { threshold } \\ \text { score }= & \end{array}$

\section{Seligman et}

al.

\begin{tabular}{|c|c|c|c|c|}
\hline $\begin{array}{l}\text { Positive } \\
\text { emotion }\end{array}$ & $\begin{array}{l}\text { In general, to what } \\
\text { extent do you feel } \\
\text { contented? (0-10; not at } \\
\text { all-completely) }\end{array}$ & $\begin{array}{l}\text { Please indicate, how } \\
\text { much of the time during } \\
\text { the past week you felt } \\
\text { calm and peaceful? (1-4; } \\
\text { none/almost none of the } \\
\text { time-all/almost all) }\end{array}$ & $\geq 2$ & $88 \%$ \\
\hline Engagement & $\begin{array}{l}\text { How often do you } \\
\text { become absorbed in } \\
\text { what you are doing? (0- } \\
\text { 10; never-always) }\end{array}$ & $\begin{array}{l}\text { How much of the time } \\
\text { would you generally say } \\
\text { you are you absorbed in } \\
\text { what you are doing? (0- } \\
10 \text {; none of the time/all } \\
\text { of the time) }\end{array}$ & $\geq 8$ & $34 \%$ \\
\hline Engagement & $\begin{array}{l}\text { In general, to what } \\
\text { extent do you feel } \\
\text { excited and interested in } \\
\text { things? (0-10; not at all- } \\
\text { completely) }\end{array}$ & $\begin{array}{l}\text { How much of the time } \\
\text { would you generally say } \\
\text { you are enthusiastic } \\
\text { about what you are } \\
\text { doing? ( } 0-10 \text {; none of the } \\
\text { time/all of the time) }\end{array}$ & $\geq 8$ & $34 \%$ \\
\hline Engagement & $\begin{array}{l}\text { How often do you lose } \\
\text { track of time while } \\
\text { doing something you } \\
\text { enjoy? (0-10; never- } \\
\text { always) }\end{array}$ & $\begin{array}{l}\text { How much of the time } \\
\text { would you generally say } \\
\text { you are interested in } \\
\text { what you are doing? (0- } \\
10 \text {; none of the time/all } \\
\text { of the time) }\end{array}$ & $\geq 8$ & $40 \%$ \\
\hline Relationships & $\begin{array}{l}\text { To what extent do you } \\
\text { receive help and support } \\
\text { from others when you } \\
\text { need it? (0-10; not at all- } \\
\text { completely) }\end{array}$ & $\begin{array}{l}\text { To what extent do you } \\
\text { receive help and support } \\
\text { from others when you } \\
\text { need it? (0-6; not at all- } \\
\text { completely) }\end{array}$ & $\geq 4$ & $68 \%$ \\
\hline Relationships & $\begin{array}{l}\text { To what extent have you } \\
\text { been feeling loved? }(0- \\
10 ; \text { not at all-completely) }\end{array}$ & $\begin{array}{l}\text { To what extent do you } \\
\text { provide help and } \\
\text { support to people you } \\
\text { are close to when they } \\
\text { need it (0-6; not at all- } \\
\text { completely)? }\end{array}$ & $\geq 3$ & $96 \%$ \\
\hline Relationships & $\begin{array}{l}\text { How satisfied are you } \\
\text { with your personal } \\
\text { relationships? (0-10; not } \\
\text { at all-completely) }\end{array}$ & $\begin{array}{l}\text { How many people are } \\
\text { there with whom you } \\
\text { can discuss intimate and } \\
\text { personal matters? (1-7; } \\
\text { none-10 or more) }\end{array}$ & $\geq 3$ & $72 \%$ \\
\hline
\end{tabular}


Operationalization \& Construct
Original Indicator Item

Selected SWI Indicator Item

\begin{tabular}{|c|c|}
\hline $\begin{array}{l}\text { Thresholds: } \\
\text { Participant categor- } \\
\text { ised as endorsing } \\
\text { this feature if SWI }\end{array}$ & $\begin{array}{l}\% \text { of SWI } \\
\text { sample } \\
\text { above this } \\
\text { threshold }\end{array}$ \\
\hline
\end{tabular}

\section{Seligman et}

al.

\begin{tabular}{|c|c|c|c|c|}
\hline $\begin{array}{c}\text { Meaning in } \\
\text { life }\end{array}$ & $\begin{array}{l}\text { In general, to what } \\
\text { extent do you lead a } \\
\text { purposeful and } \\
\text { meaningful life? (0-10; } \\
\text { not at all-completely) }\end{array}$ & $\begin{array}{l}\text { I lead a purposeful and } \\
\text { meaningful life (1-7; } \\
\text { strongly disagree- } \\
\text { strongly agree) }\end{array}$ & $\geq 6$ & $54 \%$ \\
\hline $\begin{array}{c}\text { Meaning in } \\
\text { life }\end{array}$ & $\begin{array}{l}\text { In general, to what } \\
\text { extent do you feel that } \\
\text { what you do in your life } \\
\text { is valuable and } \\
\text { worthwhile? (0-10; } \\
\text { never-always) }\end{array}$ & $\begin{array}{l}\text { I generally feel that what } \\
\text { I do in my life is } \\
\text { valuable and } \\
\text { worthwhile. (1-5; } \\
\text { strongly disagree- } \\
\text { strongly agree) }\end{array}$ & $\geq 4$ & $71 \%$ \\
\hline $\begin{array}{c}\text { Meaning in } \\
\text { life }\end{array}$ & $\begin{array}{l}\text { To what extent do you } \\
\text { generally feel you have a } \\
\text { sense of direction in } \\
\text { your life? (0-10; never- } \\
\text { always) }\end{array}$ & $\begin{array}{l}\text { To what extent do you } \\
\text { feel that you have a } \\
\text { sense of direction in } \\
\text { your life? (0-10; not at } \\
\text { all-completely) }\end{array}$ & $\geq 8$ & $35 \%$ \\
\hline $\begin{array}{c}\text { Accomplish- } \\
\text { ment }\end{array}$ & $\begin{array}{l}\text { How much of the time } \\
\text { do you feel you are } \\
\text { making progress } \\
\text { towards accomplishing } \\
\text { your goals? (0-10; never- } \\
\text { always) }\end{array}$ & $\begin{array}{l}\text { Most days I feel a sense } \\
\text { of accomplishment from } \\
\text { what I do (1-5; strongly } \\
\text { disagree-strongly agree) }\end{array}$ & $\geq 4$ & $58 \%$ \\
\hline $\begin{array}{c}\text { Accomplish- } \\
\text { ment }\end{array}$ & $\begin{array}{l}\text { How often do you } \\
\text { achieve the important } \\
\text { goals you have set for } \\
\text { yourself? (0-10; never- } \\
\text { always) }\end{array}$ & $\begin{array}{l}\text { In my daily life I get } \\
\text { very little chance to } \\
\text { show how capable I am } \\
\text { (1-5; strongly disagree- } \\
\text { strongly agree) REV }\end{array}$ & $\geq 4$ & $36 \%$ \\
\hline $\begin{array}{c}\text { Accomplish- } \\
\text { ment }\end{array}$ & $\begin{array}{l}\text { How often are you able } \\
\text { to handle your } \\
\text { responsibilities? (0-10; } \\
\text { never-always) }\end{array}$ & $\begin{array}{l}\text { There are lots of things I } \\
\text { feel I am good at (1-5; } \\
\text { strongly disagree- } \\
\text { strongly agree) }\end{array}$ & $\geq 4$ & $78 \%$ \\
\hline
\end{tabular}

